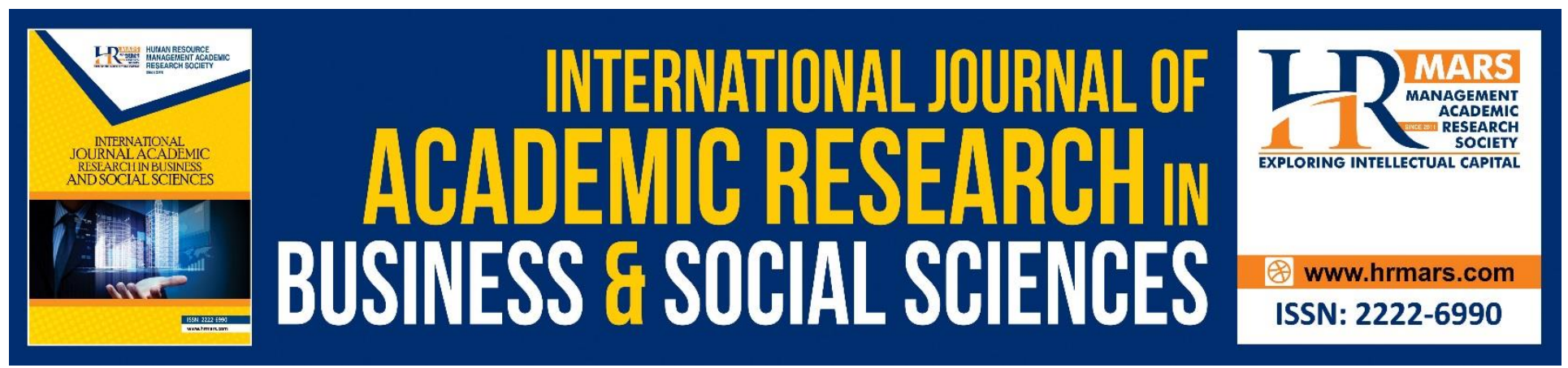

\title{
Reliability of Post Traumatic Growth Module for Domestic Violence Survivors
}

\author{
Samsiah Mohd Jais, Mohammad Nasir Bistamam, Mohammad Bazlan \\ Mustafa, Nurul Hasyimah Mat Rani
}

To Link this Article: http://dx.doi.org/10.6007/IJARBSS/v9-i6/5950

DOI: $10.6007 /$ IJARBSS/v9-i6/5950

Received: 17 April 2019, Revised: 23 May 2019, Accepted: 06 June 2019

Published Online: 28 June 2019

In-Text Citation: (Jais, Bistamam, Mustafa, \& Rani, 2019)

To Cite this Article: Jais, S. M., Bistamam, M. N., Mustafa, M. B., \& Rani, N. H. M. (2019). Reliability of Post

Traumatic Growth Module for Domestic Violence Survivors. International Journal of Academic Research in

Business and Social Sciences, 9(6), 316-325.

Copyright: (C) 2019 The Author(s)

Published by Human Resource Management Academic Research Society (www.hrmars.com)

This article is published under the Creative Commons Attribution (CC BY 4.0) license. Anyone may reproduce, distribute, translate and create derivative works of this article (for both commercial and non-commercial purposes), subject to full attribution to the original publication and authors. The full terms of this license may be seen at: http://creativecommons.org/licences/by/4.0/legalcode

Vol. 9, No. 6, 2019, Pg. $316-325$

http://hrmars.com/index.php/pages/detail/IJARBSS

JOURNAL HOMEPAGE

Full Terms \& Conditions of access and use can be found at http://hrmars.com/index.php/pages/detail/publication-ethics 


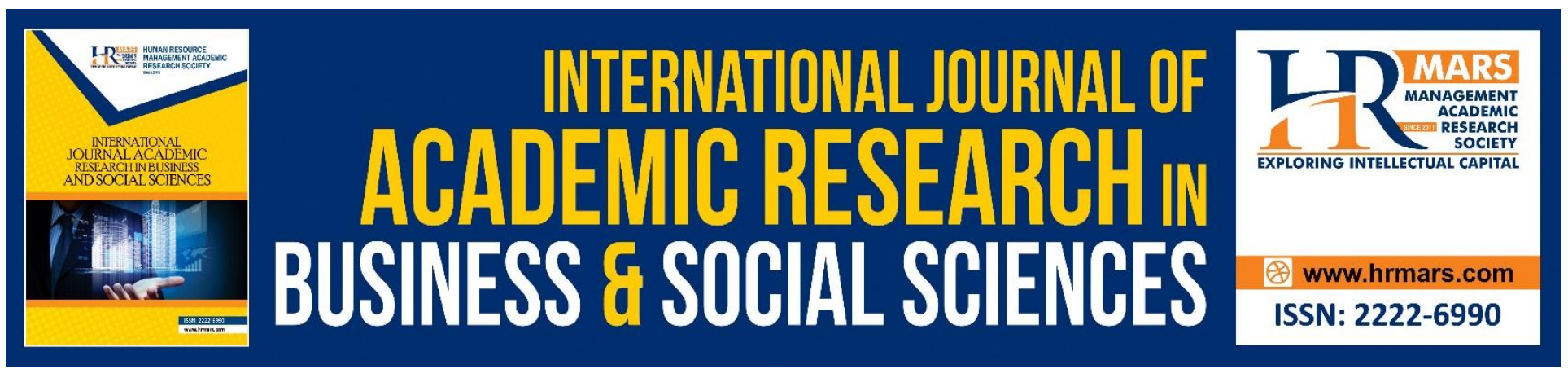

\title{
Reliability of Post Traumatic Growth Module for Domestic Violence Survivors
}

\author{
Samsiah Mohd Jais, Mohammad Nasir Bistamam, Mohammad \\ Bazlan Mustafa, Nurul Hasyimah Mat Rani \\ Counselling and Psychology Department, Faculty of Human Development, \\ Sultan Idris Education University, 35900 Tanjung Malim Perak.
}

\begin{abstract}
The purpose of this study is to obtain the reliability of Post Traumatic Growth Counseling module (PTGC). The PTGC module contains five training modules namely Module 1: Introduction to Post Traumatic Development; Module 2: Introduction of Domestic Violence; Module 3: Symptoms and Effects of Domestic Violence; Module 4: Intervention of Domestic Violence; and Module 5: Self Care which include eleven activities. The value of reliability is obtained through a written response from a group of subjects among counselors of three different settings. To measure the reliability of a total of 78 counselors were selected from three different settings, namely, the Sultan Idris Education University, the Ministry of Health Malaysia and private institutions in Malaysia. The results show that the PTGC module has a high reliability value of the overall KPPT module of .973. This finding shows that the KPPT module is acceptable and reliable and can be used in counselor training to improve the counselor's efficiency in handling domestic violence counseling. The implication of this study is directly to improve the counseling and counseling practices of counselors in the context of domestic violence, post-traumatic development and mental health particularly in the area of domestic violence counseling among counselors in various settings.
\end{abstract}

Keywords: Post Traumatic Growth Counselling module, Domestic Violence, Trauma, Crisis, Mental Health.

\section{Introduction}

Domestic violence is still considered as a personal matter of the family. Stigma and lack of understanding of domestic violence cause many individuals to take a passive approach to this issue because of the belief that it 'is not their problem'. But in fact, domestic violence is everyone's problem. Recently, a report revealed that a total of 50,658 cases of rape, incest, molestation, unnatural sex acts, sexual harassment and domestic violence were recorded from 2013 to May 2018. This shocking number originates from the data tabulated by the Women, Family and Community Development Ministry. Furthermore, the Ministry also recorded a total of 3,439 reported sex crimes and domestic violence cases from January to May 2018 (The Malay Mail, July 24, 2018). 
The statistics of domestic violence cases from the Royal Malaysian Police (PDRM) and the Ministry of Women, Family and Community Development (KPWKM) show that the rate of domestic violence cases is one of the largest contributors (40\%) of all cases of violence against women and children in Malaysia reported (WAO, 2015). Some other issues that have been reported as violence against women and children are rape cases, incest, domestic workers abuse and child abuse. Violence against women in any form highlights a larger outbreak in society, either explicitly or implied, that is, the misgivings of women who place women at lower levels than men. To change this notion and lead to non-violence society where women are treated equally, every member of the community including family and friends of the victims, government agencies concerned, and NGOs should work together to actively intervene. In line with the increased cases reported, the profession helps such counselors play an important role in addressing such social issues where the impact of domestic violence not only affects the individual's well-being (abused) but also includes collective dynamics and community harmony.

The role of a counsellor and other helping profession should not be underestimated even though there are many psychiatrists and medical doctors nowadays treating patients with mental and traumatic disorders. Moreover, counsellors are one of the main pillars who have helped their clients to achieve and stayed positive mentally. Counselling could guide an individual to realise the importance of maintaining a positive mental health in accordance with the objectives of the Ministry of Health of Malaysia, as well as with what was stressed by the World's Health Organisation (WHO). A competent counsellor would be able to help a traumatic victim to regain emotional stability and increase mobility. However, not every counsellor possesses the competence and expertise in mental health and trauma especially in recognising the symptoms of domestic violence, to diagnose, and treat clients with mental disorders and trauma. There are counsellors who have failed to diagnose accurately due to lack of knowledge in mental health, mental disorders, mental disease and trauma.

As such, the Post Traumatic Growth (PTGC) module for domestic violence survivors is developed based on the needs to have a guideline to systematically increase the knowledge and competency of counsellors and the mental health practitioner in handling cases caused by traumatic experiences due to domestic violence. This module consists of theoretical and practical aspects to increase knowledge, skills and practices of counselling. It contains five training modules and 11 activities. These five modules include the important components underlying the PTGC module which involve the aspects of awareness, knowledge and skills which could help to increase competency level of counsellors in dealing with trauma and other mental health issues related to domestic violence (Samsiah et. al, 2014).

\section{Problem Statement}

Our country is often surprised by news about domestic violence involving children and women. Astro Awani (March 10, 2016) reported that domestic violence cases investigated in 2014 were 4,807 and 1,426 of those cases were accused in court. The Ministry of Home Affairs (MOHA) reported that 358 cases of the total were sentenced. In 2015, 5,014 cases were investigated, 1,404 cases were charged in court and 146 cases were sentenced. In January 2016 only 461 cases were investigated, 151 cases were charged in court and 13 cases were sentenced. The MHOA reported that among the government's efforts to reduce the domestic violence case was to provide counseling services at the 
police station and crime prevention programs at schools. This data demonstrates the need and importance of counselors improving their efficiency in handling cases involving domestic violence such as physical, emotional, and mental abuse. According to Rusell (1974), reliability testing of a module was carried out by measuring the coping ability of counsellors towards the content of the module. Sidek and Jamaludin (2005) agreed that the method to identify the reliability of a module is similar with the method to identify the reliability of a test or a measurement tool; because both were made for a particular purpose. Abu Bakar Nordin (1987), stated that any measurement tool which has not fulfilled the requirement related to reliability is considered useless; therefore, result acquired from it is unacceptable. Julie (1995), stressed that a measurement tool is considered reliable and steady when there are proof of its reliability coefficient. As such, in order to identify the reliability coefficient of Post Traumatic Growth module, a research query was addressed: Is the reliability coefficient value of the PTGC training module high? This study was carried out to identify the reliability of PTGC training module among the counsellors in Malaysia.

\section{Research Aims}

This research was carried out to identify the reliability coefficient of the training module practised by counsellors in three different settings. In detail, this research would examine and identify the reliability coefficient of the five sub-modules of PTGC, namely i) Introduction to Domestic Violence; ii) Nature of Domestic Violence; iii) Symptoms and Effects of Domestic Violence; iv) Domestic Violence Intervention; v) Self-care.

\section{Research Method}

\section{Research Design}

A Survey was conducted to test the reliability of the built-in draft modules. The main focus is on the value of reliability through written responses from a group of subjects among counselors at the Counseling Psychology Department, Ministry of Health Malaysia and private institutions in Malaysia.

\section{Research Location}

In order to test the reliability of the module, research location was set in Psychology and Counselling Department and University Education and Research Lab (UERL) at the new campus in Proton City Tanjung Malim, Perak

\section{Research Sample}

This reliability study involved a total of 78 trainee counsellors from UPSI, Counselling Psychologist and counsellors from private institutions selected based on purposive sampling. According to Kerlinger and Lee (2000), purposive sampling could selectively select the respondents in order to fulfil the aim of research and solve research problems. The selection of respondents was based on these criteria:

i. At least a Diploma or Degree in Counseling or Counseling or psychology from any institution recognized by the government.

ii. Experience as a counselor and psychologist in a professional setting for at least 1 year. 
INTERNATIONAL JOURNAL OF ACADEMIC RESEARCH IN BUSINESS AND SOCIAL SCIENCES

Vol. 9, No. 6, June, 2019, E-ISSN: 2222-6990 @ 2019 HRMARS

Table 1: Respondents Sampling Table (Reliability Testing)

\begin{tabular}{|l|c|c|}
\hline Institution & Location & Total \\
\hline $\begin{array}{l}\text { Sultan Idris Education University } \\
\text { (UPSI) }\end{array}$ & EURL, UPSI & 23 \\
\hline Ministry of Health Malaysia & EURL, UPSI & 45 \\
\hline NGO & Kuala Lumpur & 10 \\
\hline \multicolumn{2}{|r|}{ Total } & 78 \\
\hline
\end{tabular}

\section{Research Tool}

Researchers have designed the tool to determine the reliability coefficient value of PTGC module. The items of question designed were based on the steps in each activity listed in each sub-module of PTGC. The idea was based on study by Jamaludin and Sidek (2005) and Vale (1998), in which the items of question created to test the reliability coefficient value of a module must be based on the steps in each activity as listed in the module itself. This method is also in congruent with study by Mohammad Shah (2010), Nasir (2006) and Noor (2012). In this research, the reliability was tested through the 78 counsellors from three different sectors that had participated in the PTGC workshop. These counsellors were selected based on the specified criteria. After they had completed the activities within the module, they would be given the reliability questionnaire.

\section{Statistic Data Analysis}

Reliability value of PTGC module was tested with Alpha Cronbach because this is a suitable technique to test an instrument or test-tool. A constructive reliability value for an instrument should exceed $\alpha$ value of 0.6 at significant level of .05 (Kerlinger, 1979). However, the best $\alpha$ value of a construct for an instrument should exceed 0.7 ; bearing in mind that $\alpha$ value exceeding 0.6 is still acceptable (Gay, 1996).

\section{Research Findings}

After correction, improvement and refinement, the PTGC module was finally distributed to the counsellors of three different selected sectors. During this process, the revision, correction, improvement and refinement of the PTGC module was an on-going process. This was in congruent with Rusell (1974), who stressed that the most important process in determining the reliability coefficient value of a module was the process of module testing by evaluating the feedbacks of the participants. 


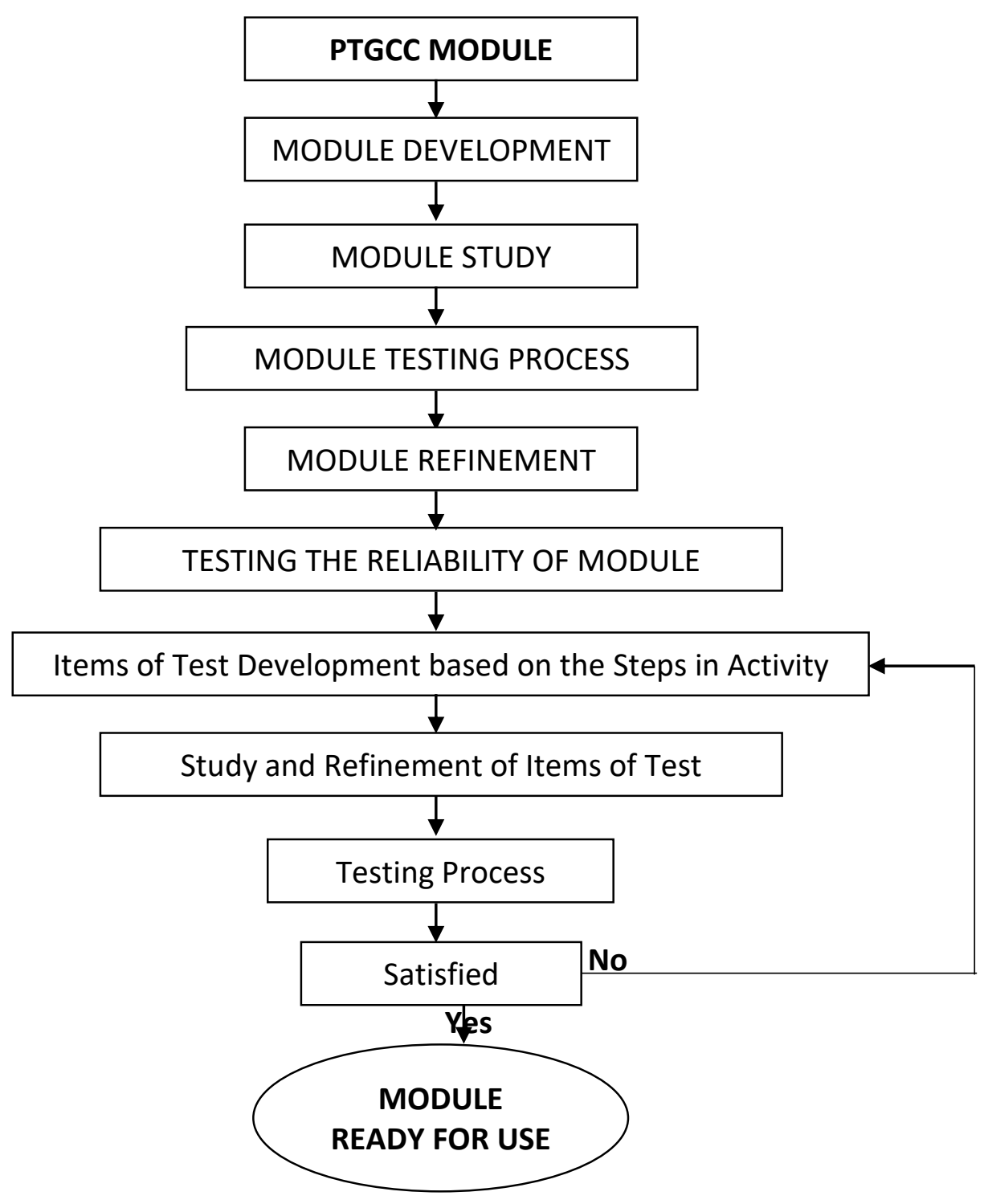

Figure 1: PTGCC Module Reliability Testing Process

\section{Findings on Reliability Testing}

This Post Traumatic Growth Counselling Module was designed to help counsellors enhance their level of competency and practices in helping victims of domestic violence in improving their coping skills. Apart from validity, a good module must be tested in terms of reliability. Sidek and Jamaludin (2005) explained that a good and usable module must possess high reliability value. As a result, this module would be consistently usable for long term.

In order to test the reliability of the module, a set of questionnaires was designed based on study by Sidek and Jamaludin (2005). The questionnaire consists of items to test the steps in each activity listed in the module in order to find out the reliability coefficient value of it. After the 
INTERNATIONAL JOURNAL OF ACADEMIC RESEARCH IN BUSINESS AND SOCIAL SCIENCES Vol. 9, No. 6, June, 2019, E-ISSN: 2222-6990 @ 2019 HRMARS

questionnaire was ready, it was distributed to a group of research subjects. These research subjects have earlier gone through the practical exercises based on the steps of activities listed in the module.

In the context of this research, the reliability was tested based on the internal consistency of the module by using Alpha Cronbach test as specified by Valette (1997). A total of 78 counsellors were involved as subjects in this research. Table 2 and 3 below showed the value of reliability for Post Traumatic Growth Counselling module for the overall module and by sub-modules.

Table 2: Overall Reliability Values of PTGC Module

\begin{tabular}{|c|c|c|c|}
\hline $\mathbf{N}$ & Total of Items & Alpha $(\boldsymbol{\alpha})$ Value & Level \\
\hline 78 & 50 & .973 & High \\
\hline
\end{tabular}

Table 2 above indicates the research findings based on the overall PTGC module's questionnaire; consisting of 50 items to test the reliability of the module based on Alpha Cronbach test analysis towards the 78 research subjects. Result shows that Alpha $(\alpha)$ value is .947 . A good reliability value for a construct of a questionnaire must be higher than $\alpha$ value 0.6 at significant level of .05 (Kerlinger, 1979). However, the best $\alpha$ value for a construct must be higher than 0.7 , while $\alpha$ value more than 0.6 is still acceptable (Gay, 1996). As such, the reliability value based on the internal consistency of the Post Traumatic Growth Counselling Module is at high level.

Table 3: Reliability Values of PTGC Module Based on Sub-constructs

\begin{tabular}{|l|c|c|c|c|}
\hline Sub-modules & $\mathbf{N}$ & $\begin{array}{c}\text { Total of } \\
\text { Items }\end{array}$ & $\begin{array}{c}\text { Alpha } \\
\text { Value }\end{array}$ & Level \\
\hline $\begin{array}{l}\text { Introduction to Domestic } \\
\text { Violence }\end{array}$ & 78 & 10 & 0.812 & High \\
\hline Nature of Domestic Violence & 78 & 10 & 0.923 & High \\
\hline $\begin{array}{l}\text { Symptoms and Effects of } \\
\text { Domestic Violence }\end{array}$ & 78 & 10 & 0.832 & High \\
\hline $\begin{array}{l}\text { Intervention for Domestic } \\
\text { Violence }\end{array}$ & 78 & 10 & 0.894 & High \\
\hline Self-care & 78 & 10 & 0.934 & High \\
\hline
\end{tabular}

Table 3 above indicates the analysis result of the questionnaire of the Post Traumatic Growth Counselling sub-modules: i) Introduction to Domestic Violence; ii) Nature of Domestic Violence; iii) Symptoms and Effects of Domestic Violence; iv) Domestic Violence Intervention; v) Self-care, which consist of 10 items for each sub-modules to test the reliability of sub-modules based on Alpha Cronbach test towards the 78 research subjects.

Result of Alpha Cronbach test analysis shows that the alpha values for the sub-module of Introduction to Domestic Violence is .812; alpha value for sub-module of Nature of Domestic Violence is .923; alpha value for sub-module for Symptoms and Effects of Domestic Violence is .832; alpha value for sub-module of Intervention for Domestic Violence is .894; and lastly the alpha value for submodule of Self Care is .934. Based on the overall findings, the reliability of each sub-module of the 
INTERNATIONAL JOURNAL OF ACADEMIC RESEARCH IN BUSINESS AND SOCIAL SCIENCES

Vol. 9, No. 6, June, 2019, E-ISSN: 2222-6990 @ 2019 HRMARS

Post Traumatic Growth Counselling module are high. This indicates that PTGC module is acceptable, reliable and usable in counsellors' practices so as to improve their competency level in helping domestic violence survivors.

\section{Discussion}

As the aim of this study is to out to identify the reliability coefficient of the training module practised by counsellors in three different settings, findings of this research confirm that the PTGC module possessed high level of reliability coefficient value. Based on the results, the Self Care sub-module scored the highest reliability coefficient value, followed by Nature of Domestic Violence sub-module, and then Intervention for Domestic Violence, Symptoms and Effects of Domestic Violence and the lowest was Introduction to Domestic Violence sub-module. All of the reliability coefficient values of the components of KKMT module were higher than .80. These were in congruent with study by Edward and Richard (1979) whereby the minimum reliability coefficient value of a measurement tool is .80 , as scored by the Intervention for Domestic Violence, Symptoms and Effects of Domestic Violence and Introduction to Domestic Violence sub-module. Moreover, the reliability coefficient value of Self Care and Nature of Domestic Violence were even higher than .90. These were also in congruent with Hopkins (1998), who stated that the reliability coefficient value of a measurement tool must be higher than .90 .

Among the sub-modules of PTGC, results showed that the Self Care sub-module scored the highest reliability coefficient value with .934 , followed by the Nature of Domestic Violence submodule with .923, Intervention for Domestic Violence sub-module with .894 and then the Symptoms and Effects of Domestic Violence sub-module with .832. The lowest scored was Introduction to Domestic Violence. Even then, both of these still fulfilled the recommended score addressed by Edward and Richard (1979), Konting (1998), Valette (1977), and Fraenkel and Wallen (1996). In conclusion, the reliability coefficient value of PTGC module was good and fulfilled the requirements set by experts from abroad.

\section{Research Implications}

Findings indicated that the PTGC module possessed high level of reliability coefficient value. In other words, this module has confirmed the objectives of the research; therefore, suitable for implementation by the target groups. Besides, this module could indirectly serve as an intervention to improve the competency level of counselling practices in general, and the domestic violence, mental health and trauma counselling practices, in specific. Besides helping to improve the coping skills of domestic violence victims, this module could also be used by school counsellors to recognise students with traumatic stress which could have lead to severe effect (such as suicide, consuming substance and run away from home) if there was no early intervention. Apart from welfare and hospital setting, PTGC module is also suitable for school, organizational, and rehabilitation center setting that often faced with cases like obvious depression, sadness, and anxiousness. Since most counsellors are well-equipped with basic and higher counselling skills, therefore, this PTGC module could serve as a value-added reference in their practices while carrying out their duty. Moreover, PTGC module could be useful in these programs to educate and to spread the information on mental health, trauma and crisis. This method had been practised by several researchers and applied in some 
INTERNATIONAL JOURNAL OF ACADEMIC RESEARCH IN BUSINESS AND SOCIAL SCIENCES Vol. 9, No. 6, June, 2019, E-ISSN: 2222-6990 (C) 2019 HRMARS

programs throughout the world (Van Houten \& Tom, 2006; McEvoy \& Ziegler, 2006; Jordons, 2002; EU Lifelong Program, 2006).

It is hope that this module would be used widely in every school in the country; even better, to serve as a reference and guidance for counsellors in various setting such as in rehabilitation center, welfare centre, in public as well as in private organizations. Schools could also design similar module to be used in schools so that the usage of modules could be extended in the future.

\section{Research Recommendation}

This research revolved around the development of PTGC module. It is hope that the next researcher would expand the study to wider scopes and look at the effect of PTGC module on counselling competency. Furthermore, study on domestic violence counselling supervision should also be explored given the complexity of this field.

Since the reliability coefficient value of the PTGC module was high; therefore, the module is recommended to be comprehensively practice in all counselling settings in Malaysia as well as in the government and private institutions that offer support services. Besides, further research related to reliability coefficient value of the PTGC module could also be practice in other states throughout the country. If the findings concerning the psychometric quality are the same as in the PTGC module; therefore, it is suggested that the PTGC module should be practice throughout the country.

The nature of the PTGC module was general. There are still plenty of competency constructs related to positive development of psychology. Among them are skills, knowledge, and personality, which could be study by future scholars. Besides, this research can be repeated using wider scope of samples while focusing on response from different settings such as school, organizational, hospital, rehabilitation center and welfare center. This would reveal the compatibility of this module in different setting. Comparison study could also be done whether on gender comparison, demography, and small treatment cluster and bigger treatment group. Moreover, module comparison based on theory could also be done such as attitude cognitive theory, individual psychology theory, and human-centered theory.

Finally, this research revealed that the reliability coefficient value of a module could be found by using the questionnaire survey approach based on steps in the module's activity as recommended by Vale (1998). As such, it is hope that future scholars would use the questionnaire survey approach based on the steps of module's activity to find out the reliability of the module.

\section{Acknowledgement}

This research receives funding from Universiti Pendidikan Sultan Idris, Malaysia through special fundamental research grant (GPU:2017-0177-109-01).

\section{References}

Nordin, A. B. (1995). Penilaian afektif. Kajang: Masa Enterprise.

Edwards, D.J.A. (2005c). Treating PTSD in South African contexts: A theoretical framework and model for the development of evidence-based practice. Journal of Psychology in Africa, 15(2), 209220. 
INTERNATIONAL JOURNAL OF ACADEMIC RESEARCH IN BUSINESS AND SOCIAL SCIENCES

Vol. 9, No. 6, June, 2019, E-ISSN: 2222-6990 @ 2019 HRMARS

EU Lifelong Programme. (2006). Lay counselling: A trainer's manual. Danish Red Cross Youth, Austria. Fraenkel, J. R. \& Wallen, N. E. (1997). How to Design and Evaluate Research in Education. 3rd.ed. New York: Mc. Graw. Hill, Inc.

Gay, L. R. (1996). Educational Research. (5th Edition). New Jersey: Prentice Hall Inc. Reprinted by S.T. Printers, Rawalpindi.

Hopkins, K. D. (1998). Educational and Psychological Measurement and Evaluation. 8th Edition. Boston: Allyn and Bacon.

Ahmad, J. (2002). Kesahan, kebolehpercayaan dan keberkesanan modul program maju diri ke atas motivasi pencapaian di kalangan pelajar sekolah negeri Selangor. Tesis Dr. Fal. Universiti Putra Malaysia.

Jordans, M. J. D. (2002). Specialized training manual in psychosocial counselling for trafficked youth. IPEC Trafficking in Children-South Asia (TICSA).

Kerlinger, F. N. (1979). Foundation of behavioural research. Ed. Ke 2. New York: Holt Rinehart \& Winston.

Kerlinger, F. \& Lee, H. (2000). Foundation of behavioural research. Ed. Ke 4. New York: Forth Worth.

McEvoy, M. \& Ziegler, M. (2006). Best practical manual for stopping the violence. Counselling Program in British Columbia. Department of Justice Canada.

Saper, M. N. (2012). Pembinaan modul bimbingan 'Tazkiyah An-Nafs' dan kesanya ke atas religiositi dan resiliensi remaja. Dr. Fal. Universiti Utara Malaysia.

Konting, M. M. (1998). Kaedah Penyelidikan Pendidikan. Edisi Keempat. Kuala Lumpur: Dewan Bahasa Dan Pustaka

Arip, (2010). Kesan kelompok bimbingan ke atas konsep kendiri, kelangsangan dan resiliensi di kalangan remaja. Tesis Dr. Fal. Universiti Kebangsaan Malaysia Bangi.

Mohammad Nasir Bistamam (2006). Kesan Kaunseling Kelompok Ke Atas Penyesuaian Remaja Berisiko. Tesis Dr. Fal. Universiti Kebangsaan Malaysia Bangi.

Rusell, J. D. (1974). Modular instruction: a guide to the design, selection, utilization and evaluation of modular materials. United States: Publishing Company.

Jais, S. M., Bistamam, Mohammad N., Arif, Mohammad A. S. M., Khan, Khan A. W. R., \& Sipon, S. (2014). Pembinaan model integrasi kesihatan mental dan trauma sebagai strategi peningkatan kecekapan amalan kaunseling kesihatan mental dan trauma di Malaysia. Fundamental Research Grant Scheme (FRGS). Universiti Pendidikan Sultan Idris, Tg. Malim Perak.

Noah, S. M., \& Ahmad, J. (2005). Pembinaan modul: Bagaimana membina modul latihan dan modul akademik. Serdang: Penerbit Universiti Putra Malaysia.

Valette, Rebecca, M. (1977). Modern language testing: A hand book. (2nd Edition). $\quad$ New York: Harcourt Brace Jovanovich.

Vale, J. D. (1998). Traditional reliability. http://www.ece.edu/-koopman/de. (23 Julai 2002).

Van Houten, H., \& Tom, K. (2006). Trainer's manual for rape trauma counsellors in Kenya. Ministry of Health, Kenya. 